\title{
Prospective randomized comparison of low pressure versus standard pressure pneumoperitoneum in laparoscopic cholecystectomy
}

(Ann Coll Med Mosul 2018; 40 (1): 41-45).

Hisham A. Alatrakchi, Firas M. Alchalabi, Khalaf R. Alluwaizi

Department of Surgery, College of Medicine, University of Mosul, Mosul, Iraq.

Correspondence: Firas M. Alchalabi. firas.m.alchalabi@gmail.com.

Received: $1^{\text {st }}$ Dec. 2013; Accepted: $22^{\text {nd }}$ Jan. 2014.

\section{ABSTRACT}

Background: Postoperative shoulder tip pain occurs frequently following laparoscopic cholecystectomy. The origin of shoulder pain is partly understood, but it is commonly assumed that the cause is overstretching of the diaphragmatic muscle fibers due to high rate of insufflations. The aim of this study is to compare the frequency and intensity of shoulder tip pain between low pressure $(7 \mathrm{mmHg})$ and standard-pressure (14 $\mathrm{mmHg}$ ) pneumoperitoneum after laparoscopic cholecystectomy.

Setting: Aljumhori Teaching Hospital during the period from January 2011 to June 2012.

Design: A prospective randomized study.

Patients and methods: One hundred and forty consecutive patients undergoing elective laparoscopic cholecystectomy were randomized prospectively into two groups, either low pressure (group A) or standard pressure (group B) pneumoperitoneum, they were blinded to the research doctors who assessed the patients during the postoperative period by the visual analogue scale (VAS) of pain. Comparative analysis between the two groups included gender, mean age, operative time, complication rate and postoperative shoulder tip pain.

Results: The demographic data were nearly similar in the two groups. There were no significant intraoperative complications in both groups, likewise the mean operative time was nearly similar in either group. The mean frequency and intensity of postoperative shoulder tip pain assessed by visual analogue scale was less in group $A$ than in group $B$.

Conclusion: No difference was found between low pressure and standard pressure pneumoperitoneum in the duration of operation and complication, but low pressure pneumoperitoneum tended to produce lower incidence and intensity of shoulder tip pain.

Keywords: Gall stones, laparoscopy, low pressure, standard pressure.

$$
\begin{aligned}
& \text { مقارنة مستقبلية عشوائية بين الضغط الواطئ والضغط القياسي } \\
& \text { للصفاق في عمليات إستئصال المرارة بالناظور } \\
& \text { هشام أحمد الأطرقجي، فراس محمود الجلبي، خلف رشيد اللويزي } \\
& \text { فرع الجراحة، كليةّة الطب، جامعة الموصل، الموصل، العراق الجيل }
\end{aligned}
$$

الخلاصة أناف

أهداف الدراسة: هو مقارنة شدة وتكرار الآم الكتف بين الضغط الواطئ (V ملم زئبق) والضغط المعياري (عا الملم زئبق) داخل

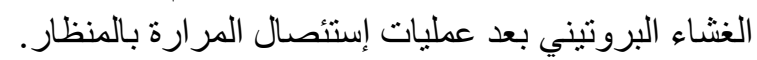

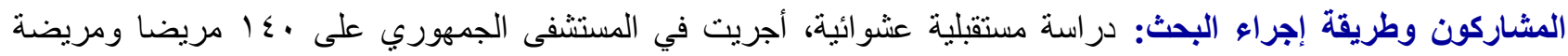

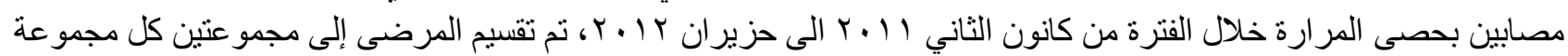

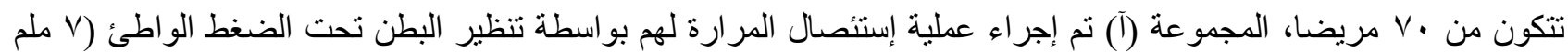

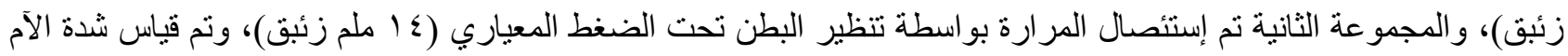

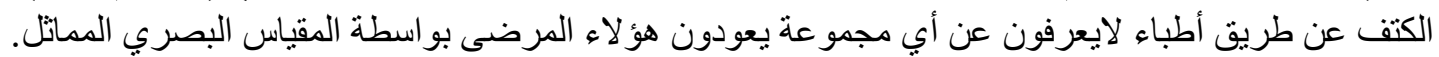




$$
\begin{aligned}
& \text { النتائج: لا يوجد أي زيادة في فترة إجر اء العملية أو المضاعفات في المجموعة (أ) مقارنة بالمجموعة (ب) وهي متقاربة جدا بين }
\end{aligned}
$$

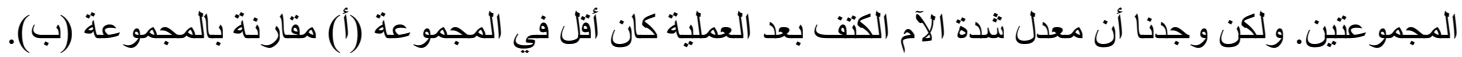

$$
\begin{aligned}
& \text { الإستنتاج: لايوجد فرق في فترة إجر اء العملية و المضاعفات بين الضغط الو اطنئ والضغط المعياري في عمليات إستئصسال المرارة }
\end{aligned}
$$

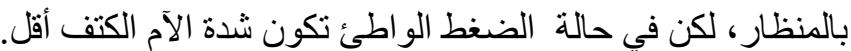

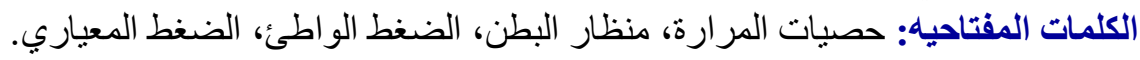

\section{INTRODUCTION}

W ithin an exceptionally short time, laparoscopic cholecystectomy (LC) has widely replaced open cholecystectomy (OC) as the standard treatment for symptomatic cholelithiasis. ${ }^{1}$ Since the introduction of (LC), pneumoperitoneum at $15 \mathrm{mmHg}$ has been commonly used for all laparoscopic procedures. Despite its widespread use, this pressure is not without its problems and disadvantages. ${ }^{2}$ Alternative surgical technique, low- pressure $\mathrm{CO}_{2}$ maintained pneumoperitoneum, has been used in an attempt to reduce the impact on the cardiopulmonary function associated with the application of conventional pressure (14$15 \mathrm{mmHg})^{3,4,5}$ Serious and potentially lethal complications including DVT, MI, atelectasis and pneumonia, especially in elderly or high risk patients, have been attributed to the physiological effects of pneumoperitoneum at $14 \mathrm{mmHg}^{2}$

During laparoscopic cholecystectomy adequate working space is required in the abdomen for good exposure that contributes to satisfactory results and patients safety. ${ }^{5}$ The most common method to create working space in the abdomen is carbon dioxide insufflation into the peritoneal cavity and then holding it at constant pressure. ${ }^{5,6}$ Low pressure pneumoperitoneum $(7 \mathrm{mmHg})$ is enough to warrant a sufficient operative space without a need for conversion in a significant percentage of laparoscopic operations. ${ }^{7}$

Shoulder tip pain frequently occurs after (LC) making postoperative recovery less comfortable. The etiology of postoperative pain is extremely complex and a precise evaluation of the various causes is still difficult to achieve. In particular, shoulder-tip pain is presumed to be linked to $\mathrm{CO}_{2}$ insufflation, and its intensity is often so strong that analgesics must be administered frequently. The reported incidence of shoulder-tip pain following (LC) varies between $30 \%$ and $50 \% .{ }^{6}$ It is well known that the visceral peritoneum is sensitivefree to pain on sharp cutting and puncture wounds, on the other hand, it is highly sensitive to distension, tearing and separation. ${ }^{8}$ Visceral pain and shoulder pain account for most of the pain experienced after LC, whereas patients complain more of the parietal pain after laparotomy. ${ }^{1}$

An emerging trend has been the use of low pressure pneumoperitoneum instead of the standard pressure pneumoperitoneum in an attempt to lower the impact on the human physiology while providing adequate working space. .,9,10 $^{5}$

This method appears to have little adverse effect on the cardiac and respiratory functions. Other possible advantages of low pressures during pneumoperitoneum appear to be lower incidence of shoulder tip pain in the post-operative period and better quality of life in the early postoperative period. ${ }^{5,11,12}$

Pain is a subjective sensation, and its measurement and analysis are difficult. Visual analogue scale (VAS) is usually presented as 100$\mathrm{mm}$ horizontal line on which the patient pain intensity is represented by points between the extremes of 'no pain at all' and ' worst pain imaginable'. Its simplicity, reliability, and validity, as well as its ratio scale properties make (VAS) the optimal tool for describing pain severity and intensity. ${ }^{1}$

Aim of the study is to evaluate the influence of low pressure pneumoperitoneum on the feasibility, safety, and the postoperative shoulder tip pain pneumoperitoneum during laparoscopic cholecystectomy.

\section{PATIENTS AND METHODS}

One hundred forty patients with American Society of Anesthesiologists (ASA) grade 1 or 2 having symptomatic gall stones scheduled for elective laparoscopic cholecystectomy during the period from January 2011 to June 2012 were enrolled in this study. The patients were divided into two 
groups (70 in each group) and were randomly allocated to one of the two groups. In group A which represent the odd numbers, low pressure pneumoperitoneum $(7 \mathrm{~mm} \mathrm{Hg}$ ) was generated, and in group $B$ which represent the even numbers, standard pressure pneumoperitoneum $(14 \mathrm{mmHg})$ was created. Exclusion criteria included acute cholecystitis, choledocholethiasis, and previous abdominal surgery, in addition five patients who were changed from low to standard pressure pneumoperitoneum because of poor visualization of the surgical field were excluded from the study; four of them were obese females, and one was muscular male. All patients were admitted to the hospital the day before surgery, for investigations, anesthetic consultation, and had an informed consent.

All the surgical procedures were performed under standard general anesthesia, by surgeons experienced in LC. Pneumoperitoneum was created with $\mathrm{CO}_{2}$ insufflation using the open (Hasson) method until abdominal pressure of either $(7 \mathrm{~mm} \mathrm{Hg})$ low pressure group or (14 $\mathrm{mmHg}$ ) standard pressure group was reached. In all patients, the routine 4 ports and the standard American technique was achieved. Residual carbon dioxide was evacuated at the end of the procedure, through the open valve trocars, and then removal of the trocars under vision. Duration of surgery, intraoperative complications, and bile spillage were recorded but no drain was left. All patients were prescribed postoperative analgesia with diclofenac $75 \mathrm{mg}$.

The degree of postoperative shoulder-tip pain was assessed by means of a visual analogue scale (VAS) at 3, 6, 12, and $24 \mathrm{~h}$, postoperatively. The pain scale, with scores ranging from 0 (no pain) to 10 (unbearable pain), was recorded by a doctor who was blind to the group allocation of the patients, allowing patients to mark a point along the scale that represented their pain at that time. The patients were aware and informed that the scale is analyzing the presence and intensity of the shoulder pain alone, but not the postoperative abdominal pain. The postoperative shoulder pain was assessed in a double blinded manner; neither the patient nor the assessor were aware of the technique to which the patients has been randomized. Analgesic requirement and duration of hospital stay were recorded.

\section{RESULTS}

The age, gender, and the ASA grade were similar in both groups. There were no differences in the mean duration of surgery, length of hospital stay or intraoperative bile spillage Table 1.

The proportion of patients that complained of shoulder tip pain presenting during the first 24 hours after operation was lower in group $A$ than in group B. In group A 12 (19\%) out of 70 patients complained of shoulder tip pain in the postoperative period, while in group B 23 (33\%) out of 70 patients complained of shoulder tip pain which was highly significant as in Table 2 . Shoulder tip pain started after 3-6 hours and peaked in both groups after 12 hours, then gradual improvement was felt after that time.

The mean intensity of shoulder tip pain was significantly lower in group A than in group B. Pain score revealed that postoperative shoulder tip pain was significantly less intense at 12 and 24 hours postoperatively. The shoulder tip pain score was very low in group $\mathrm{A}$ at $24 \mathrm{~h}$ compared with group $B$, and the mean intensity of the shoulder tip pain exceeded a score of 3 at 24 hour in group B as in Table 3.

Table 1. Patients details (mean $\pm S D$ ).

\begin{tabular}{|c|c|c|c|}
\hline & $\begin{array}{c}\text { Group A } \\
\text { low } \\
\text { pressure }\end{array}$ & $\begin{array}{l}\text { Group B } \\
\text { high } \\
\text { pressure }\end{array}$ & $\begin{array}{c}p \\
\text { value }\end{array}$ \\
\hline $\begin{array}{l}\text { Mean age } \\
\text { (years) } \pm S D\end{array}$ & $\begin{array}{l}41.7 \pm \\
12.3\end{array}$ & $\begin{array}{c}39.5 \pm \\
11.9\end{array}$ & 0.449 \\
\hline Female/Male & $58 / 12$ & $54 / 16$ & 0.582 \\
\hline $\begin{array}{l}\text { Operation time } \\
\text { (min) } \pm S D\end{array}$ & $\begin{array}{l}50.7 \pm \\
12.7\end{array}$ & $\begin{array}{c}47.4 \pm \\
10.6\end{array}$ & 0.729 \\
\hline $\begin{array}{l}\text { Postoperative } \\
\text { hospital stay }\end{array}$ & 1.23 & 1.12 & 0.322 \\
\hline Bile spillage & 9 & 7 & 0.290 \\
\hline $\begin{array}{l}\text { Analgesic (not } \\
\text { required) }\end{array}$ & 27 & 22 & 0.356 \\
\hline
\end{tabular}

Table 2. No. of patients with postoperative shoulder tip pain.

\begin{tabular}{lccc}
\hline Group & Group A & Group B & $\begin{array}{c}p \\
\text { value }\end{array}$ \\
\hline $\begin{array}{l}\text { Postoperative } \\
\text { Shoulder pain }\end{array}$ & $12(19 \%)$ & $23(33 \%)$ & 0.001 \\
\hline
\end{tabular}


Table 3. postoperative shoulder tip pain (mean $\pm S D$ ).

\begin{tabular}{cccc}
\hline $\begin{array}{c}\text { Time after } \\
\text { surgery }(\mathrm{h})\end{array}$ & $\begin{array}{c}\text { Group A } \\
(\mathrm{n}=70)\end{array}$ & $\begin{array}{c}\text { Group B } \\
(\mathrm{n}=70)\end{array}$ & $p$ value \\
\hline 3 & $0.83 \pm 0.71$ & $2.46 \pm 1.31$ & 0.000 \\
6 & $3.20 \pm 1.51$ & $4.06 \pm 2.11$ & 0.055 \\
12 & $4.91 \pm 1.36$ & $6.37 \pm 1.91$ & 0.001 \\
24 & $1.14 \pm 1.03$ & $4.31 \pm 1.51$ & 0.000 \\
\hline
\end{tabular}

In both groups there were patients who did not require any analgesic medication 27 (38.5\%) in group $A$, and $22(31.4 \%)$ in group B, with no significant difference between the two groups. During the first 24 hours 6 patients in the lowpressure group and 10 patients in the highpressure group required extra analgesic medication for severe pain, but also it was not significantly different between the two groups.

Apart from postoperative pain, there were no significant intraoperative or postoperative complications in either group. There was no correlation between duration of surgery and postoperative shoulder tip pain. There were no significant difference between the two groups in terms of time to return to oral food, and discharge.

\section{DISCUSSION}

Although pain occurring post laparoscopic surgery is less severe and of shorter duration than that after open surgery, it still causes considerable discomfort and increases stress response in some patients. ${ }^{13}$ The maintenance of elevated intraabdominal pressure for the duration of the procedure is associated with numerous undesirable consequences including postoperative shoulder tip pain. ${ }^{14}$ The etiology and pathogenesis of the shoulder tip pain is only partly understood, but it is commonly assumed that the cause is overstretching of the diaphragmatic muscle fibers owing to the high rate of insufflation, and the low insufflation rate significantly reduces shoulder pain. ${ }^{6,13}$ Some authors claim that it may be caused by diaphragmatic irritation by a chemical material, as carbon dioxide may be transformed by combining with fluid in the peritoneal cavity into an irritative carbonic acid. ${ }^{15}$ This opinion is supported by the observation that, patients experience less pain if nitrous oxide is used instead of carbon dioxide in laparoscopic cholecystectomy. ${ }^{16}$
This study demonstrated that the incidence of shoulder tip pain after low pressure pneumoperitoneum was significantly lower as compared to the standard pressure laparoscopic cholecystectomy, 23 (33\%) patients had shoulder pain in group B, while only $12(19 \%)$ in group A with a ( $p$ value 0.001$)$. This result differs from the study done by Kanwer who found no significant difference between the two groups, but he found lower demand for analgesia in the low pressure group. $^{5}$ These results are slightly different from those of Mir $\mathrm{Y}$ et $\mathrm{al}^{14}$ where only $10 \%$ of their low pressure group developed shoulder pain. On the other hand, studies conducted by Sandhu $\mathrm{T}^{13}$ Sarli ${ }^{6}$ and Berczynski ${ }^{11}$ showed that the incidence of shoulder tip pain in low pressure group is lower than shoulder tip pain in standard pressure group, but this results did not reach statistical significance.

In the present study the mean intensity of postoperative shoulder tip pain at 3,6, 12, $24 \mathrm{~h}$ recorded on VAS was lower in patients who underwent laparoscopic cholecystectomy with low pressure pneumoperitoneum compared with standard pressure. The difference between low pressure and standard pressure was highly significant at 3,12 , and $24 \mathrm{hrs}$, but did not reach statistical significance at $6 \mathrm{~h}$ postoperatively, although the intensity of pain was lower in the low pressure group. These results are different from the results of Sarli $L^{6}$ and Yasir $M,{ }^{14}$ also it is different from the study done by Mahmut $\mathrm{K}$ et al where the mean intensity pain was lower in the low pressure group than the standard pressure group, but it was statistically not significant. Many centers have reported that LC performed with low pressure pneumoperitoneum resulted in a better quality of life postoperatively as compared to LC performed with standard pressure, this is attributed to lower incidence and intensity of postoperative pain in low pressure pneumoperitoneum group with fewer requirement of analgesics in the postoperative period..$^{5}$

None of our patients needed conversion to open cholecystectomy with no major complication in both groups, and the bile leakage is comparable between the two groups. Likewise the operative time and the duration of hospital stay were comparable in the two groups. These results warrant the feasibility and the safety of low 
pressure LC. The majority of the patients in group A could be operated on easily and safely with good visualization of the Calot's triangle, but when the operative field is not well visualized in low pressure LC, it can be increased to the standard pressure, as in five of our patients who were obese or muscular; and this may be attributed to the thick abdominal wall which requires more pressure to lift. In agreement with our study, Sarli ${ }^{6}$ mentioned that he had no significant complications and no significant difference in the time of operation.

In this study the analgesic requirements for shoulder tip pain were less in low pressure laparoscopic cholecystectomy as compared to standard pressure laparoscopic cholecystectomy, but the difference between the two did not reach statistical significance, this result was comparable with that of Sandhu. ${ }^{13}$

In conclusion, no difference was found between low pressure and standard pressure pneumoperitoneum regarding duration of operation and complication, but low pressure pneumoperitoneum resulted in lower incidence and lesser intensity of shoulder tip pain, although it did not reach statistical significance at some recordings. However, low pressure may affect the visual field especially in obese or muscular patients, therefore it is not recommended in these patients.

\section{REFERENCES}

1. Mahmut $\mathrm{K}$, Tamer $\mathrm{E}$, Mesut $\mathrm{T}$, et al. Randomized, prospective comparison of postoperative pain in low versus high pressure pneumoperitoneum. ANZ J Surg 2005; 75: 693-696.

2. Davides D, Birbas K, Vezakis A. Routine low pressure pneumoperitoneum during laparoscopic cholecystectomy. Surg Endosc 1999; 13: 887-889.

3. Yih-Huei $U$, chen -Yi Kuo, Kuo Chang Wen. Randomized trial of low pressure carbon dioxide elicited pneumoperitoneum versus abdominal wall lifting for laparoscopic cholecystectomy. J Chin Med Assoc 2007; 70(8): 324-330.
4. Bhandari D, Tidke S, Sharma V, et al. Hemodynamic changes associated with laparoscopic cholecystectomy: effect of oral clonidine premedication. Journal of pharmacy 2012; 2(4): 72-77.

5. kanwer DB, Kaman L et al. Comparative study of low pressure versus standard pressure pneumoperitoneum in laparoscopic cholecystectomy- a randomized controlled trial. Gastroenterology 2009; 30(3): 171-174.

6. Sarli L, Costi R, et al. Prospective randomized trial of low pressure pneumoperitoneum for reduction of shoulder tip pain following laparoscopy. B J Surg 2000; 87: 1161-1165.

7. Duck-Kyoung Kim, IL- Young Cheong, Ga-Young Lee et al. Low pressure pneumoperitoneum does not reduce the incidence and severity of postoperative nausea and vomiting following gynecologic laparoscopy. Korean $\mathrm{J}$ Anesthesiol 2006; 50 (6): 36-42.

8. Hodzic E, Imamovic S, Hasukic S, et al. Postoperative pain in open vs. laparoscopic cholecystectomy with and without local application of anesthetic. Medicinski Glasnik 2011; 8 (2): 243-248.

9. Joris J, Cigarinil L, Legrand $M$, et al. Metabolic and respiratory changes after cholecystectomy performed via laparotomy or laparoscopy. Br J Anaesth 1992; 63: 3415.

10. Baraka A, Jabbour S, Hammond R, et al. End tidal carbon dioxide tension during laparoscopic cholecystectomy. Anaesthesia 1994; 49: 403-6.

11. Barczynski M, Herman RM. Aprospective randomized trial on comparison of low pressure and standard pressure pneumoperitoneum for laparoscopic cholecystectomy. Surg Endosc 2003; 17:533-538.

12. Wallace $\mathrm{DH}$, Serpell MG, Baxter JN, et al. Randomized trial of different insufflation pressures for laparoscopic cholecystectomy. $\mathrm{Br}$ J Surg 1997; 84: 455-8.

13. Sandhu T, Yamada S, Ariyakachon V, et al. low pressure pneumoperitoneum versus standard pneumoperitoneum in laparoscopic cholecystectomy, a prospective randomized clinical trial. Surg Endosc 2009; 23(5): 1044-1047.

14. Yasir M, Mehta KS, Banday VH, et al. Evaluation of postoperative shoulder tip pain in low pressure versus standard pressure pneumoperitoneum during laparoscopic cholecystectomy. The surgeon 2012; 10(2): 71-4.

15. Nyerges A. Pain mechanisms in laparoscopic surgery. Semin laparosc surg 1994; 1: 215-18.

16. Aitola $\mathrm{P}$, Airo I, Kaukinen $\mathrm{S}$, et al. comparison of $\mathrm{N}_{2} \mathrm{O}$ and $\mathrm{CO}_{2}$ pneumoperitoneums during laparoscopic cholecystectomy with special reference to postoperative pain. Surg Laparosc Endosc 1998; 8:140-4. 